\title{
The effect of shape hollow block brick on the economy and the heat transfer coefficient
}

\author{
Marwa Nossier Hamdan El-Hamaida \\ Architectural Engineering Department, The Higher Institute of Engineering and Technology in Al- \\ Arish,Egypt . \\ E-mail address: archmarwa1@gmail.com
}

\begin{abstract}
The building is the main place for humans to feel safe and comfortable. Also, the building does not depend on economic dimension only but depends on the social and environmental dimensions. For that, it is very important to achieve thermal comfort in the building to increase people's ability to be productive and feel comfortable. It notes that the highest ratio of building constructed with a brick of concrete in North Sinai - Egypt. Therefore, giving special attention to making the building constructed with a brick of concrete low cost is very essential in maintaining the cohesion of the three dimensions of green architecture building. Therefore, the study will include changing the shape of the concrete hollow brick with the same materials and its ratio in manufacturing. To construct the building in less time and decrease construction laborer and the material which use in construction. Also, the study will include some cross sections in external walls to achieve the most suitable section in-wall appropriate with the environment of north Sinai that decreases the overall heat transfer coefficient on the wall of the building. Additionally, that compares the cost of building for the traditional building constructed by brick of concrete with the building constructed by new brick of concrete. Finding will improve the economic and environmental dimension for building constructed with new concrete brick, which can impact directly in the social dimension. Because using the new hollow brick will decrease the energy consumption and the cost with a ratio of $7 \%$ in every part during a building's life cycle.
\end{abstract}

Keywords: Low-cost building; Thermal comfort; Energy consumption; Heat Transfer.

\section{Introduction}

The building is a major worry for all people as the well-being of a country is reflected in taking people pleasure in a certain standard of living. ${ }^{[1]}$ The green economy is a development of the state in which the industrial economy adapts to human health needs and the environment. ${ }^{[2]}$ The goals that motivate the planning and design of green buildings ${ }^{[3]}$ (address environmental degradation, improved human health, and comfort, economic, political, societal goals) Goals reflect the unique needs of the human spirit. A lot of studies refer to green construction leading to important economic savings. ${ }^{[4]}$ Therefore, the main importance must be to the envelope of the building. 
The envelope of the building has an important role in saving the internal climate in the building stable. ${ }^{[5]}$ The main element in the external envelope is the wall because it has the biggest space. So, we should care about choosing the construction system and its element and material to improve thermal comfort indoor buildings. ${ }^{[6]}$ When it has controlled the heat transfer throw the wall and raise the level of thermal insulation for the wall, ${ }^{[7]}$ it had decreased indoor heat gains during summer and indoor heat losses during winter. ${ }^{[8]}$ Additionally, that will decrease energy consumption inside the building which help reduce the cost. So, the external envelope construction affects the cost during the life cycle of the buildings. ${ }^{[9]}$

According to that, the construction envelope control at the Heat Transfer through the wall. Climate change is the major challenge we face, consequently should be focused on reducing energy consumption through control in the building envelope construction. ${ }^{[10]}$ Concrete hollow block masonry is widely used. ${ }^{[11]}$ Hollow brick is assumed that a hole may be treated as a medium with thermal resistance. . ${ }^{[12]}$ Heat transfer through perforated bricks can be governed by conduction through the brick body, conduction through the filler in the holes in addition to radiation and natural convection in the holes. ${ }^{[13]}$ Also, the thermal behavior of hollow bricks could be improved by filling hollow cavities with heat-resistant materials such as PCM. [14] Currently, a lot of studies focused on compressive strength and the thermal conductivity of the cement composite. . ${ }^{[15]}$ Besides that, some studies referred to using recycled material with cement in concrete products such as brick. ${ }^{[16]}$

In a building the walls, floors, and roofs are the most important sections, which can be analyzed distinctively based on the needs, thus, improving the speed of construction and reducing the construction cost. . ${ }^{[17]}$ Improved thermal comfort keeps the indoor temperature at the comfortable range for a large time and helps in decreasing the electrical consumption energy of buildings. ${ }^{[18]}$ However, the impact of solar radiation on building envelopes varies dramatically according to seasonal and spatial variation. ${ }^{[19]}$ A thermally insulating envelope can significantly decrease indoor heat gains during summer and indoor heat losses during winter. ${ }^{[20]}$ The ventilation, air-conditioning (HVAC), and Heating demand account for $40 \%$ of household energy use. ${ }^{[21]}$ The energy-efficiency of air-conditioning is the main part of building energy-saving. ${ }^{[22]}$ Thermal properties such as thickness and conductivity and the effective energy performance are analyzed in Energy Plus. ${ }^{[23]}$

The aim of the study is to change the shape of traditional hollow brick to connect without material between layers and improve the economy and the heat transfer coefficient. Additionally, Analyze the new hollow brick's role in the economy and the heat transfer coefficient at the building. The thermal behavior of new hollow bricks will analysis with Fourier's law. Also, the energy consumption at heating and cooling, Structure Costs, HVAC Costs, Lighting Costs will analysis with a simulation program design-builder.

\section{Methodology:}

This paper will Analyze the new hollow brick's role in the economy and the heat transfer coefficient at the building. This brick has been designed to connect without material between layers. Additionally, it has the same material as a traditional hollow brick which has been used in north Sinai especially in El-Arish city, Egypt. the new hollow brick effect in two phases the building construction phase and the building operating phase. 
This paper included three phases. The first phase had compared the new hollow brick with traditional hollow brick. Then, the second phase had analyzed the thermal behavior of new hollow bricks. Finally, the third phase depended on program analysis, which studied the energy consumption at heating and cooling, Structure Costs, HVAC Costs, Lighting Costs.

The first phase compares the new hollow brick with traditional hollow brick:

This part study properties changing the shape of concrete hollow brick to improve the properties and performance during the stage of construction building and the indoor environment during use the building. Table 1 explain different between traditional hollow brick and new hollow brick. The new concrete hollow brick had designed to be connected without material which will save the time and number of construction laborers during the construction building phase, also will decrease the cost of construction building by saving the material which uses between the brick to make it connect. Additionally, designed to save a comfortable environment indoor building by decreasing the overall heat transfer coefficient on the wall of the building.

Table 1. compare between the traditional concrete hollow brick and The New concrete hollow brick

\begin{tabular}{|l|l|l|l|}
\hline & The traditional concrete hollow brick
\end{tabular}




\section{The second phase had analyzed the thermal behavior of new hollow bricks.:}

To analyze the thermal behavior of new hollow bricks has done compared with the ten traditional types of brick, which used usually in building to know the difference between them in heat transfer coefficient as explained in Table (2) below. This study will show suitable sections in the wall that can use in building construction, which reduces Heat Transfer through this wall. Therefore, the decrease the heat transfer will help to save energy consumption in buildings. So will compare the coefficient of heat transmission in some cross sections in traditional walls with walls that use the new brick without opening. This comparison had been used Fourier's law ${ }^{[24]}$ :

$\mathbf{q}=\frac{\mathbf{1}}{\mathbf{R}}(t 1-t 2)$

$R t=\frac{1}{F i}+\frac{X a}{K a}+\frac{X b}{K b}+\frac{X c}{K c}+\cdots \cdots+\frac{X n}{K n}+\frac{1}{F o}$

$\mathbf{U}=\frac{1}{\mathrm{Rt}}$

$Q=U \cdot A \cdot\left(t_{1}-t_{2}\right)$

(Q) The heat flux density.

(R) Thermal Resistance. $\mathbf{M}^{2} \mathbf{c}^{\circ} / \mathbf{w}$

(X) Thickness (cross-section of material)

(F) Film coefficient, W/m2. $\mathrm{C}^{\circ}$.

(U) Overall heat transfer coefficient, $\mathbf{w} / \mathbf{m}^{2} \mathbf{c}^{\circ}$.

(k) Thermal conductivity for material, W/M.C ${ }^{\circ}$

$\Delta \mathrm{T}=\left(t_{1}-t_{2}\right)$

$\left(t_{1}\right)$ The external temperature $=32.75 \mathrm{C}^{\circ}$ (The average temperature in summer)

$\left(t_{2}\right)$ The internal temperature $=25 \mathrm{C}^{\circ}$

$\mathrm{F} i=9.37 \mathrm{~W} / \mathrm{m} 2 . \mathrm{C}^{\circ}$. (Static air)

Fo $=22.7 \mathrm{~W} / \mathrm{m} 2 . \mathrm{C}^{\circ}$. With speed $24 \mathrm{~km} / \mathrm{h}$

(Wind in summer season)

According to Egyptian code (ECP 306 - 2005)

Heat transfer coefficient for Contains: (k)

Cement Portland $=.175$ W/M.C ${ }^{\circ}$

Air cavity $=.025 \mathrm{~W} / \mathrm{M} . \mathrm{C}^{\circ}$

Brickwork, dense $=1.4 \mathrm{~W} / \mathrm{M} . \mathrm{C}^{\circ}$

Polystyrene $=.03 \mathrm{~W} / \mathrm{M} . \mathrm{C}^{\circ}$

Thermal conductivity units are $[\mathrm{W} /(\mathrm{m} \mathrm{K})$ 
Table 2. explain Thermal conductivity through eleven types of walls

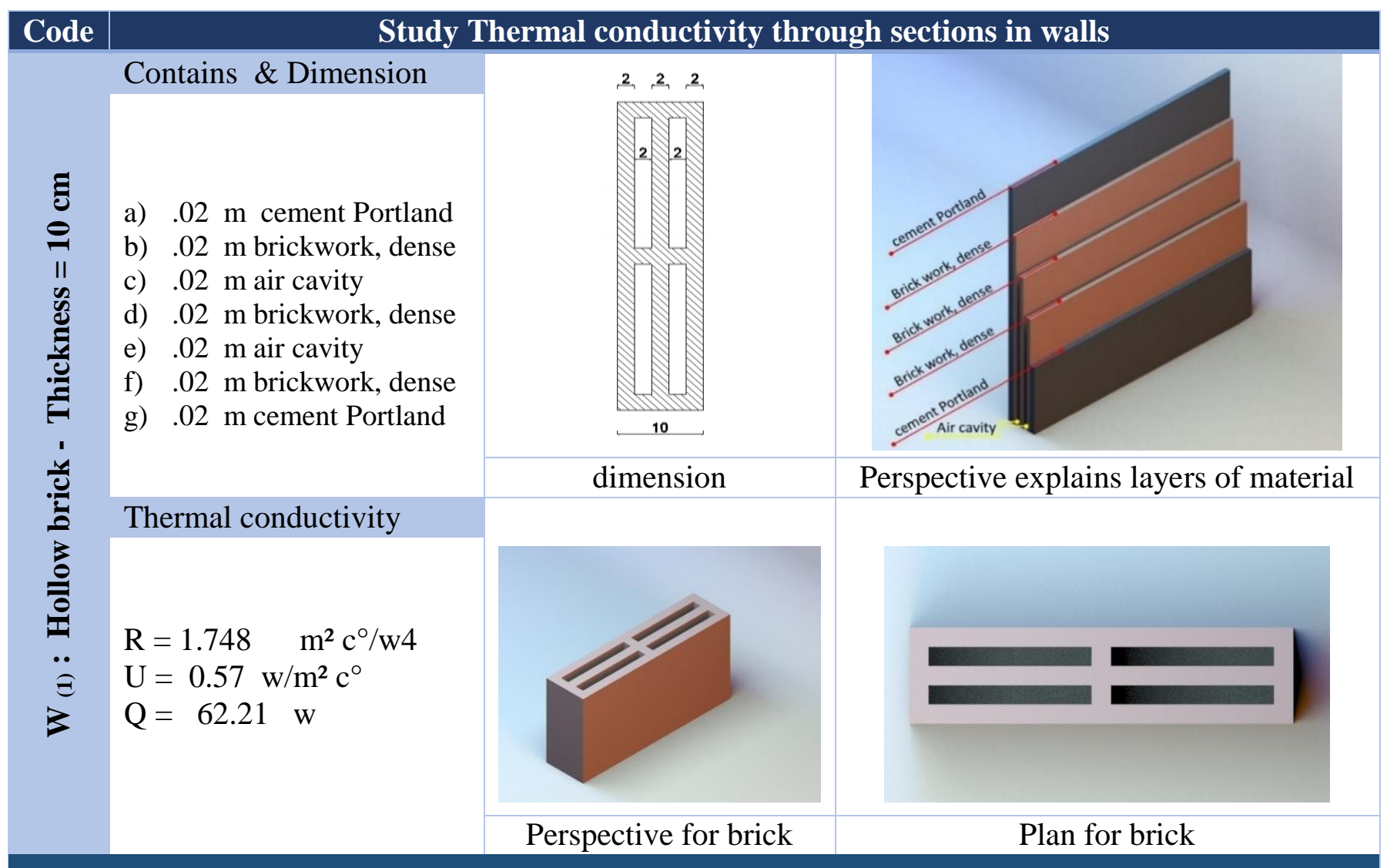

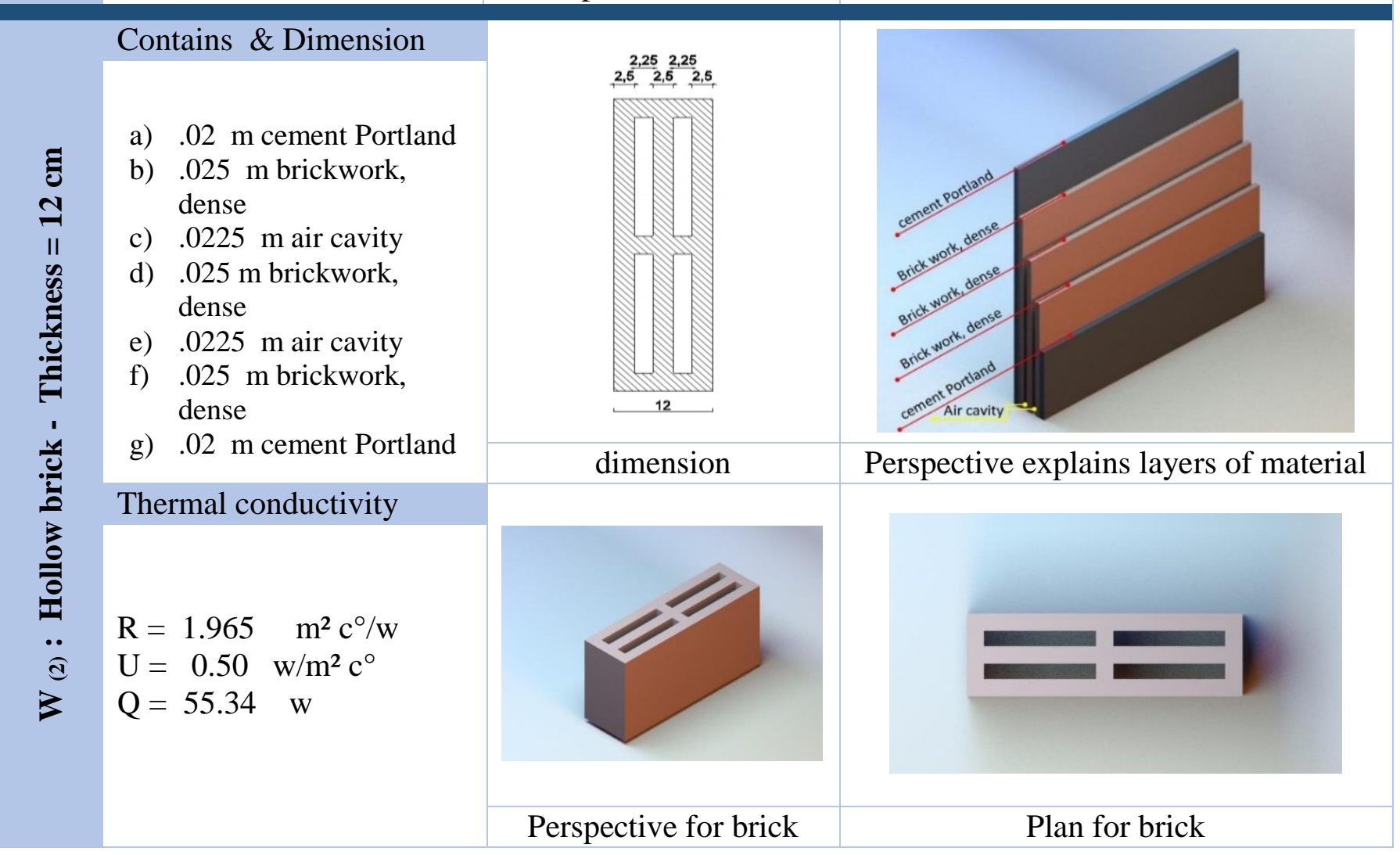




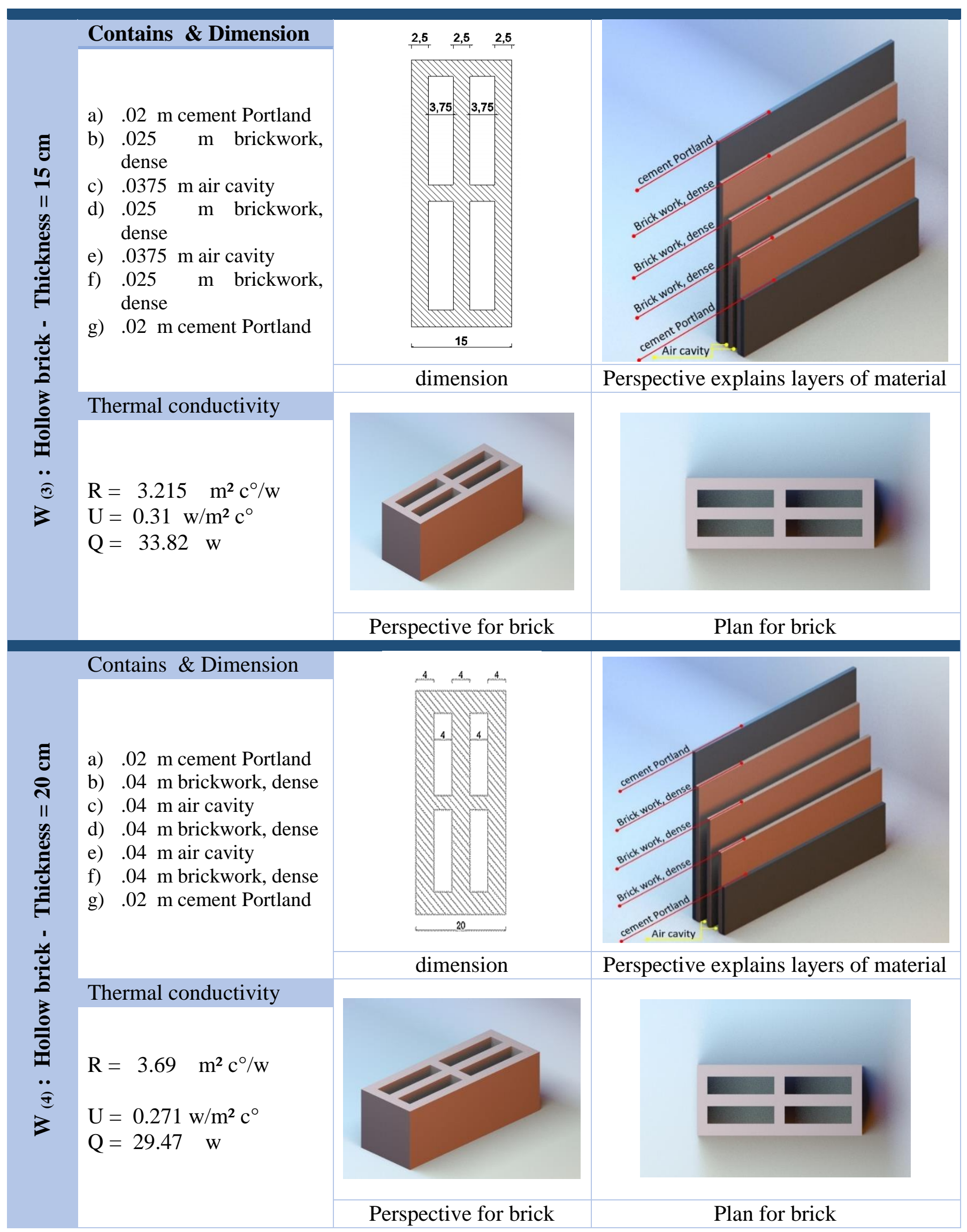



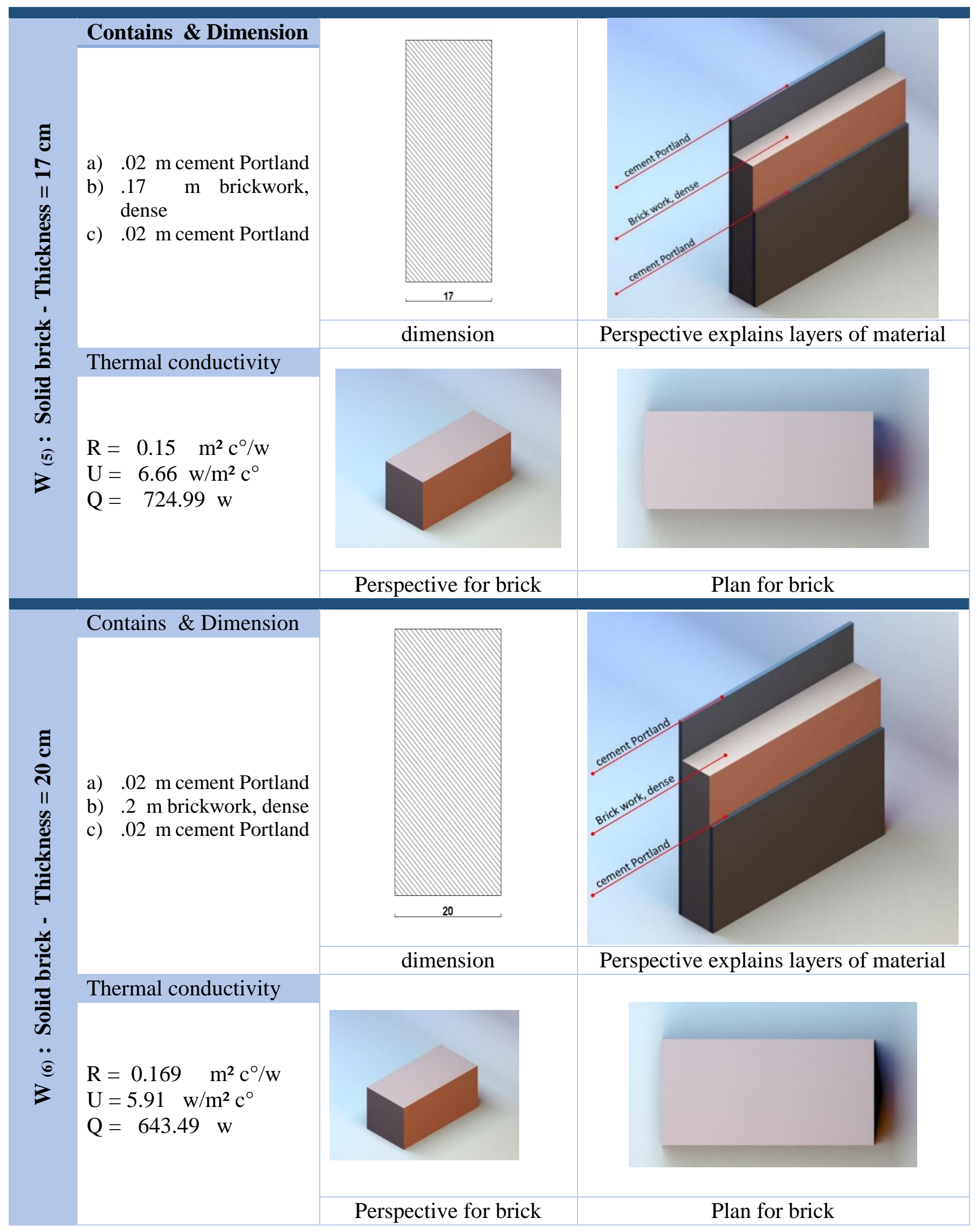

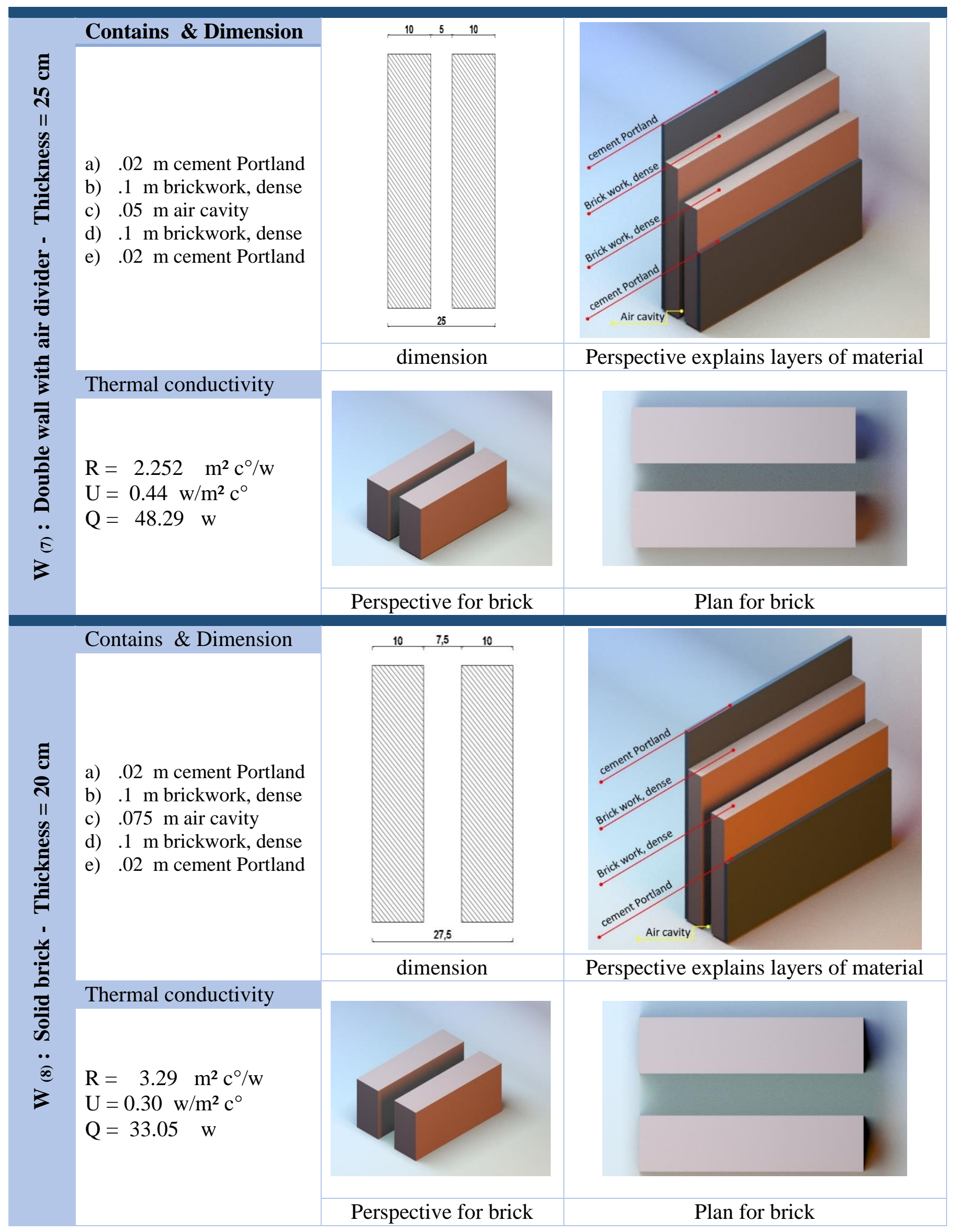

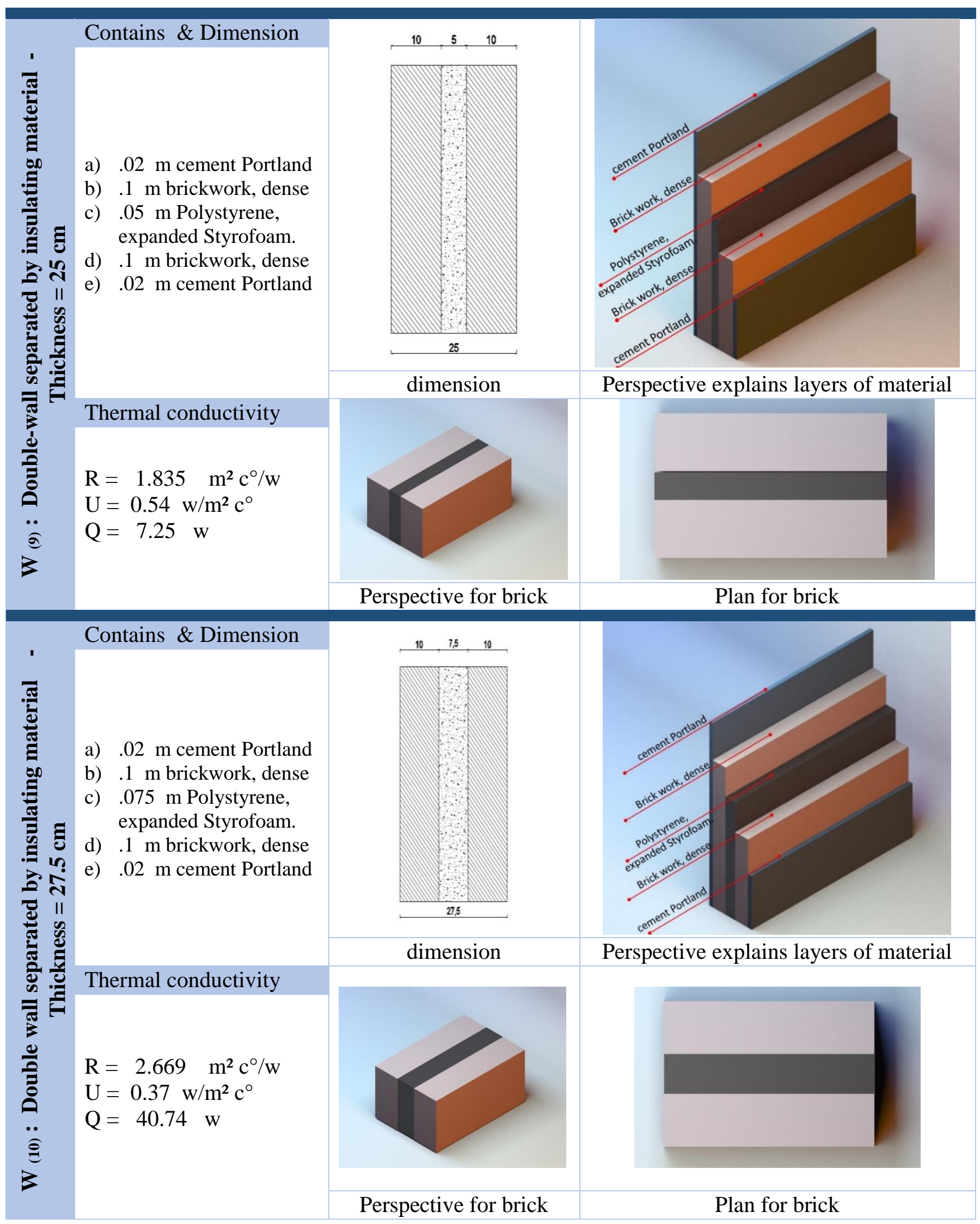


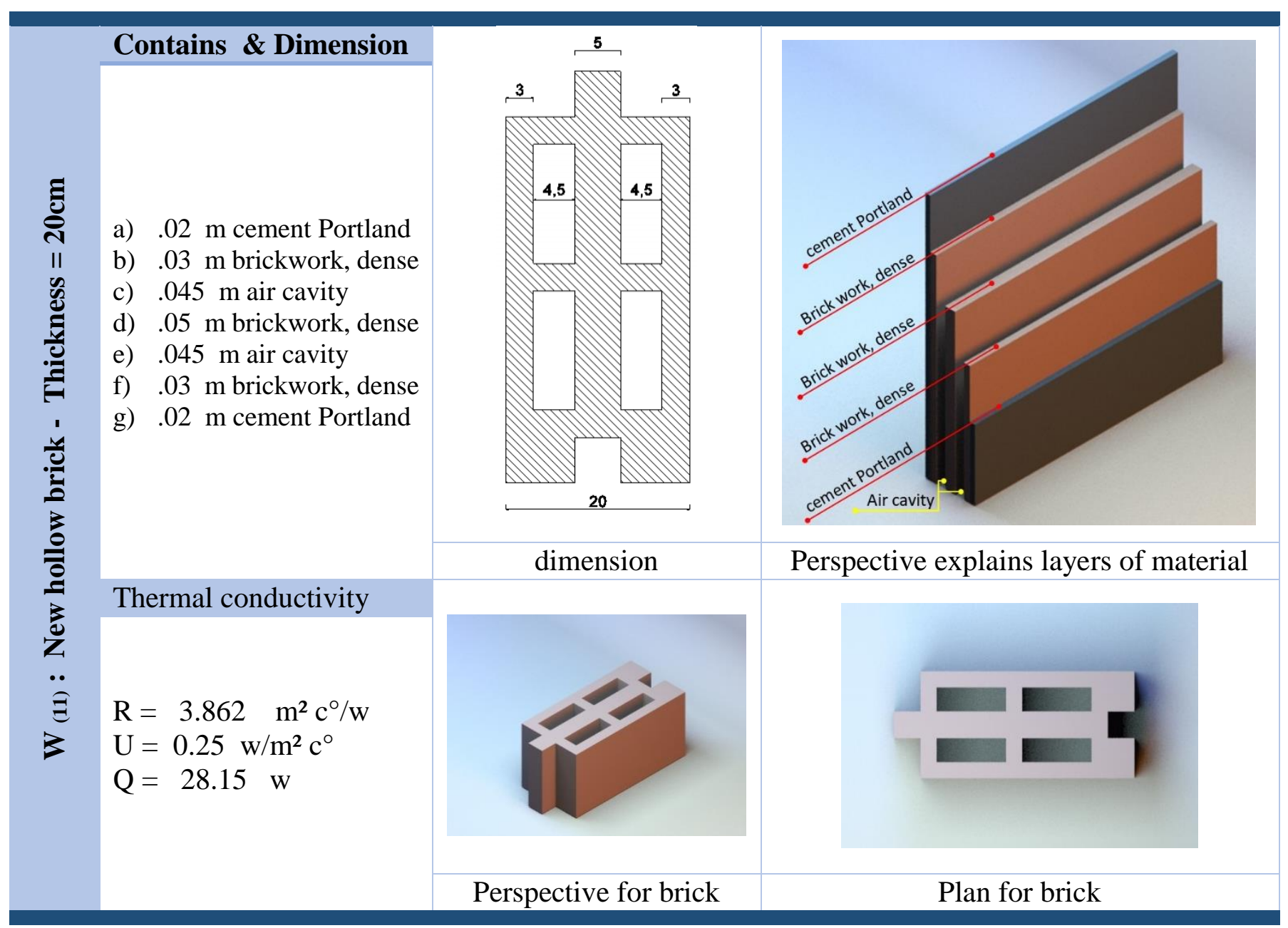

The third phase used program analysis design-builder:

To know the coefficient for the effect of change shape hollow brick on studied the energy consumption at heating and cooling, Structure Costs, HVAC Costs, Lighting Costs had been used the simulation program design-builder. Also has been choosing the most two types of brick used in construction building to compare with the new hollow block brick. Then has been measured three outputs from the program (The Temperature and heat loss for wall - The energy usage at heating and cooling - The cost), to compare the result for the three types.

The most type of brick used in construction building:

1. Hollow brick - Thickness $=12 \mathrm{~cm}$

2. Hollow brick - Thickness $=15 \mathrm{~cm}$

3. New hollow brick- Thickness $=20 \mathrm{~cm}$ ( the case study) 
According to that, three models of room with an area of $\left(25 \mathrm{~m}^{2}\right)$ without opening and a height of $(3 \mathrm{~m})$ have been designed inside the design-builder program. The first model has been used in wall construction hollow brick with a thickness of $12 \mathrm{~cm}$. The second model has been used in wall construction hollow brick with a thickness of $15 \mathrm{~cm}$. The third model has been used in wall construction hollow brick with a thickness of $20 \mathrm{~cm}$, this model is the case study. Consequently, has been simulated the three model with this program and has been given these results which show in the below tables. The program has been given the energy consumption in the building and the cost. Energy consumption depends on two types heating and cooling in the building. The cost depends on three parts structure costs, HVAC costs, and lighting costs in the building.

Energy consumption: The two tables below explain the result of analysis models in the design-builder simulation program. The energy consumption at district cooling in the three models of buildings is shown in Table 3. The energy consumption at district heating in the three models of the building is shown in Table4.

Table 3. Explain District Cooling between the three models of building

\begin{tabular}{|c|c|c|c|}
\hline & Building 1 & Building 2 & Building 3 \\
\hline $\begin{array}{c}\text { District } \\
\text { Cooling [kWh] }\end{array}$ & 5162.95 & 5069.69 & 4779.22 \\
\hline
\end{tabular}

Table 4. Explain District heating between the three models of building

\begin{tabular}{|c|c|c|c|}
\hline & Building 1 & Building 2 & Building 3 \\
\hline $\begin{array}{c}\text { District } \\
\text { Heating [kWh] }\end{array}$ & 408.64 & 409.69 & 306.4 \\
\hline
\end{tabular}

The cost: The estimated building construction cost data shown below is based on 'per gross internal floor area' costs of services, sub-structure, and frame construction. The cost of constructions and glazing is based on the 'per surface area' cost data from the constructions and glazing database. Surface finish costs are also calculated from actual building surface areas and entered surface finish per area costing data.

The three tables below explain the result of analysis models in the design-builder simulation program. The Structure Costs for the three models of buildings are shown in Table 5. The HVAC Costs for the three models of buildings are shown in Table 6. The Lighting Costs for the three models of buildings are shown in Table 7. 
Table 5. Explain The Structure Costs for the three models of buildings

\begin{tabular}{|l|c|c|}
\hline \multicolumn{1}{|c|}{ Structure Costs } & $\begin{array}{c}\text { Floor Area } \\
(\mathbf{m} 2)\end{array}$ & Cost (GBP) \\
\hline Building (1) & 22.7 & $4,758.18$ \\
\hline Building (2) & 22.1 & $4,638.90$ \\
\hline Building (3) & 21.2 & $4,443.60$ \\
\hline
\end{tabular}

Table 6. Explain HVAC Costs for the three models of buildings

\begin{tabular}{|l|c|c|}
\hline \multicolumn{1}{|c|}{ HVAC Costs } & $\begin{array}{c}\text { Floor Area } \\
(\mathbf{m} 2)\end{array}$ & Cost (GBP) \\
\hline Building (1) & 22.7 & $3,398.70$ \\
\hline Building (2) & 22.1 & $3,313.50$ \\
\hline Building (3) & 21.2 & $3,174.00$ \\
\hline
\end{tabular}

Table 7. Explain Lighting Costs for the three models of buildings

\begin{tabular}{|l|c|c|}
\hline \multicolumn{1}{|c|}{ Lighting Costs } & $\begin{array}{c}\text { Floor Area } \\
(\mathbf{m} 2)\end{array}$ & Cost (GBP) \\
\hline Building (1) & 22.7 & $1,359.48$ \\
\hline Building (2) & 22.1 & $1,325.40$ \\
\hline Building (3) & 21.2 & $1,269.60$ \\
\hline
\end{tabular}

\section{Result and discussion:}

The first phase compares the new hollow brick with traditional hollow brick: The comparison between the new hollow brick and the traditional hollow block explains the benefit of the new hollow brick.

benefits of the new hollow brick at many sides such as:

- Decrease the time of building construction because of the type of new brick putting it together so easily.

- The new brick does not need material to connect.

- Reduce the number of construction laborers. 
- The thermal behavior of hollow bricks could be improved by filling hollow cavities with heat-resistant materials. Which that will help in:

o increase feeling comfortable indoor building

○ thermal comfort which can impact directly in decreased use equipment (which is used for cooling in summer- heating in winter)

$\circ$ achieve thermal comfort and decrease the use of equipment that affects energy consumption

All these benefits will help to decrease the cost for the building during the construction phase and at the operating phase. After defining the benefit of the new hollow brick, had been made five samples of new hollow brick and tested its Compressive strength. The result of this test explains the average compressive strength for five samples of new hollow brick $=4.5 \mathrm{~N} / \mathrm{mm}^{2}$. The compressive strength for the new hollow brick has been compared with the compressive strength according to the Egyptian code (N 204 - 2015) in the Table 8 below.

Table 8. Explain the compressive strength for new hollow brick and Egyptian code

\section{Compressive strength $(\mathrm{N} / \mathrm{mm} 2)$}

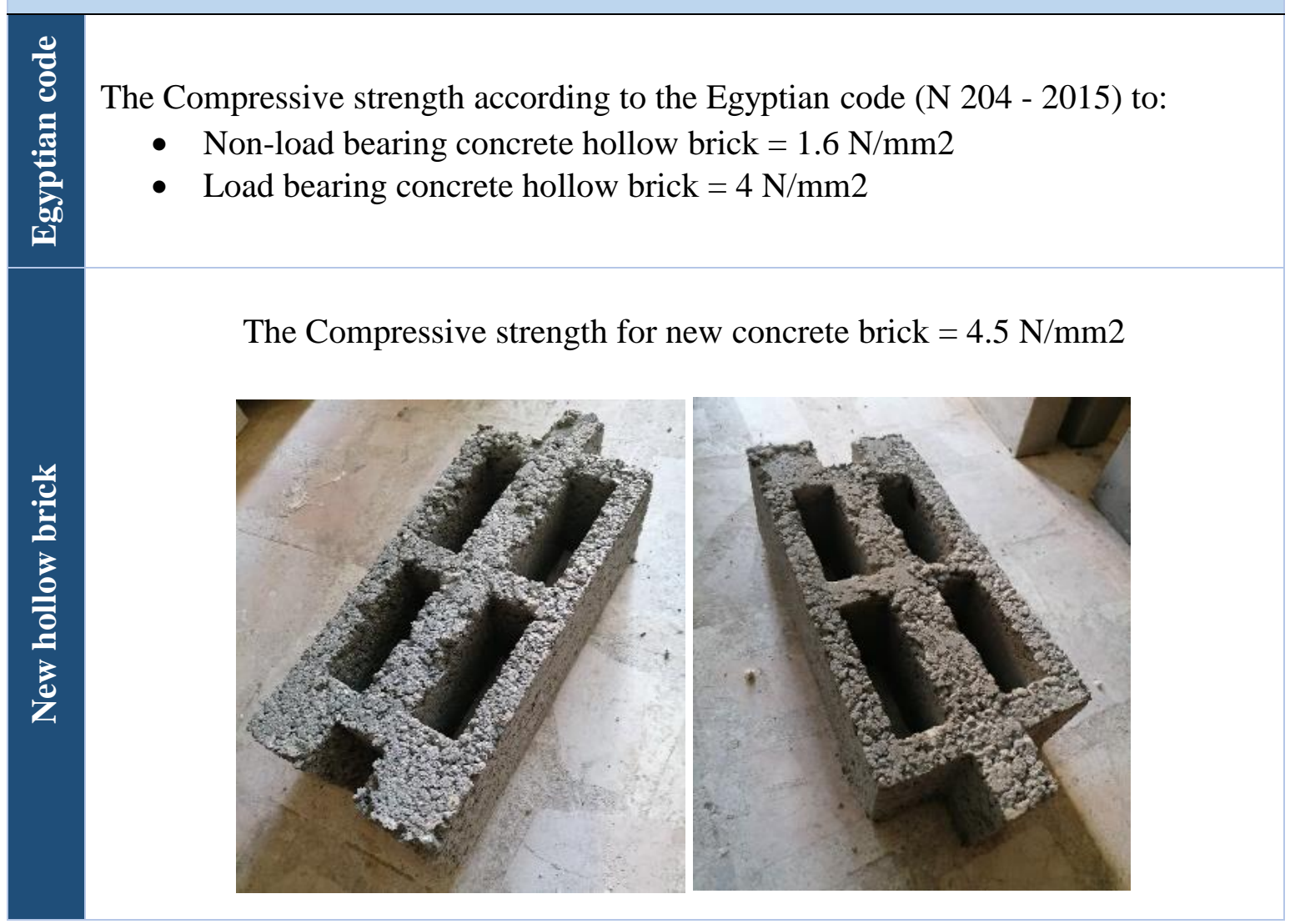




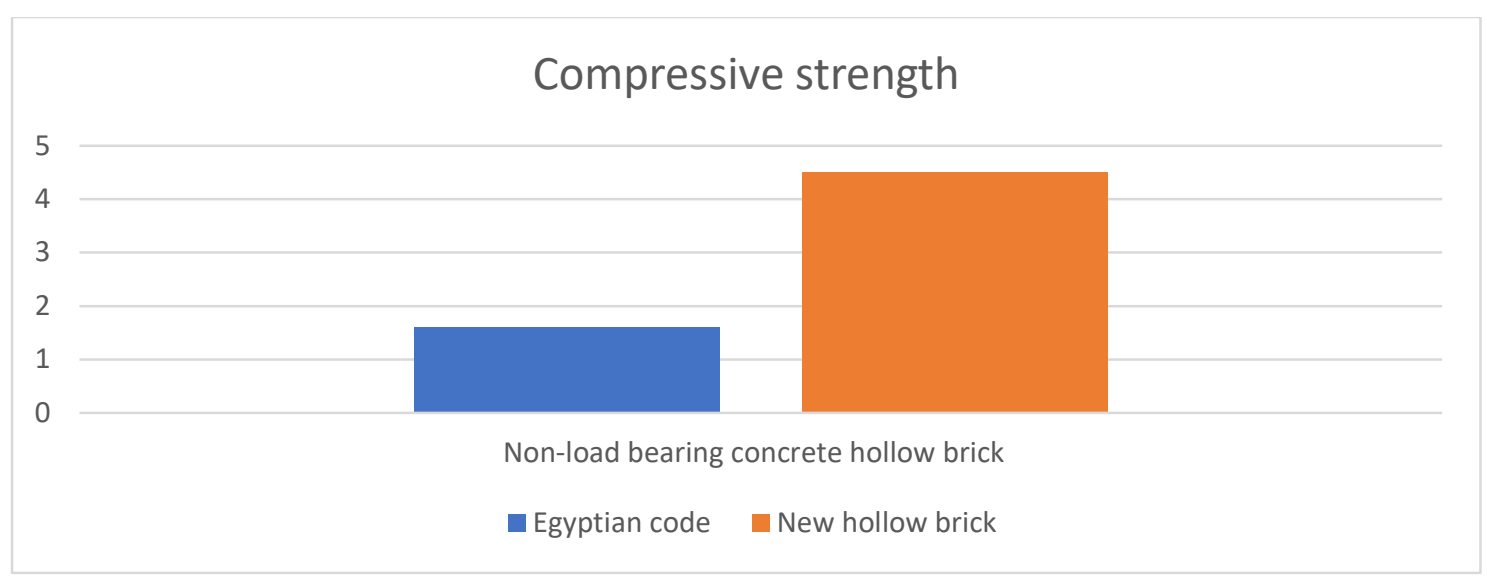

Figure 1. Explain the compare compressive strength between the Egyptian code and New hollow brick in the case of non-load bearing concrete hollow brick

The compare compressive strength to New hollow brick is higher than the compressive strength wanted in Egyptian code in the case of non-load bearing concrete hollow brick. New hollow brick is the highest compressive strength percentage of $65 \%$ with compressive strength wanted in Egyptian code in the case of non-load bearing concrete hollow brick as showed in Figure 1.

According to that the changing shape of the hollow brick didn't negatively affect the compressive strength. So, the new hollow brick can be used in building construction in the wall not loaded bearing.

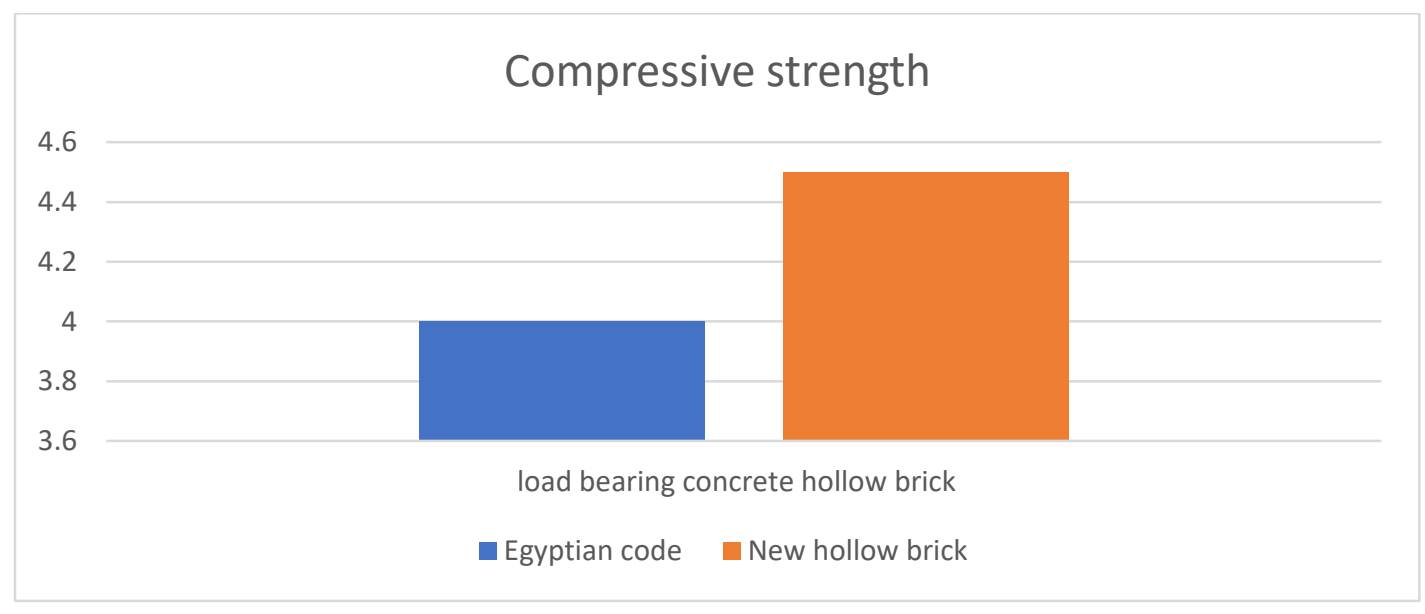

Figure 2. Explain the compare compressive strength between the Egyptian code and New hollow brick in the case of load-bearing concrete hollow brick

The compare compressive strength to New hollow brick is higher than the compressive strength wanted in Egyptian code in the case of load-bearing concrete hollow brick. New hollow brick is the highest compressive strength percentage of 
$12 \%$ with compressive strength wanted in Egyptian code in the case of load-bearing concrete hollow brick as showed in Figure 2.

According to that the changing shape of the hollow brick didn't negatively affect the compressive strength. So, the new hollow brick can be used in building construction in the wall-loaded bearing.

The second phase had analyzed the thermal behavior of new hollow bricks.:

Comparative analysis of the heat flux density through all eleven cross-sections walls without opening with use used Fourier's law has given this result in the Table 9 below:

Table 9. Explain the heat flux density through the eleven cross-sections walls during the summer season.

\begin{tabular}{|c|c|c|}
\hline $\mathbf{N}$ & Code & Thermal Resistance. $\mathbf{M}^{\mathbf{2}} \mathbf{c}^{\circ} / \mathbf{w}$ \\
\hline $\mathbf{1}$ & $\mathrm{W}_{(1)}$ & 1.748 \\
\hline $\mathbf{2}$ & $\mathrm{W}_{(2)}$ & 1.965 \\
$\mathbf{3}$ & $\mathrm{W}_{(3)}$ & 3.215 \\
\hline $\mathbf{4}$ & $\mathrm{W}_{(4)}$ & 3.69 \\
\hline $\mathbf{5}$ & $\mathrm{W}_{(5)}$ & .15 \\
\hline $\mathbf{6}$ & $\mathrm{W}_{(6)}$ & .169 \\
\hline $\mathbf{7}$ & $\mathrm{W}_{(7)}$ & 2.252 \\
\hline $\mathbf{8}$ & $\mathrm{W}_{(8)}$ & 3.29 \\
\hline $\mathbf{9}$ & $\mathrm{W}_{(9)}$ & 1.835 \\
\hline $\mathbf{1 0}$ & $\mathrm{W}_{(10)}$ & 2.669 \\
\hline $\mathbf{1 1}$ & $\mathrm{W}_{(11)}$ & 3.862 \\
\hline
\end{tabular}

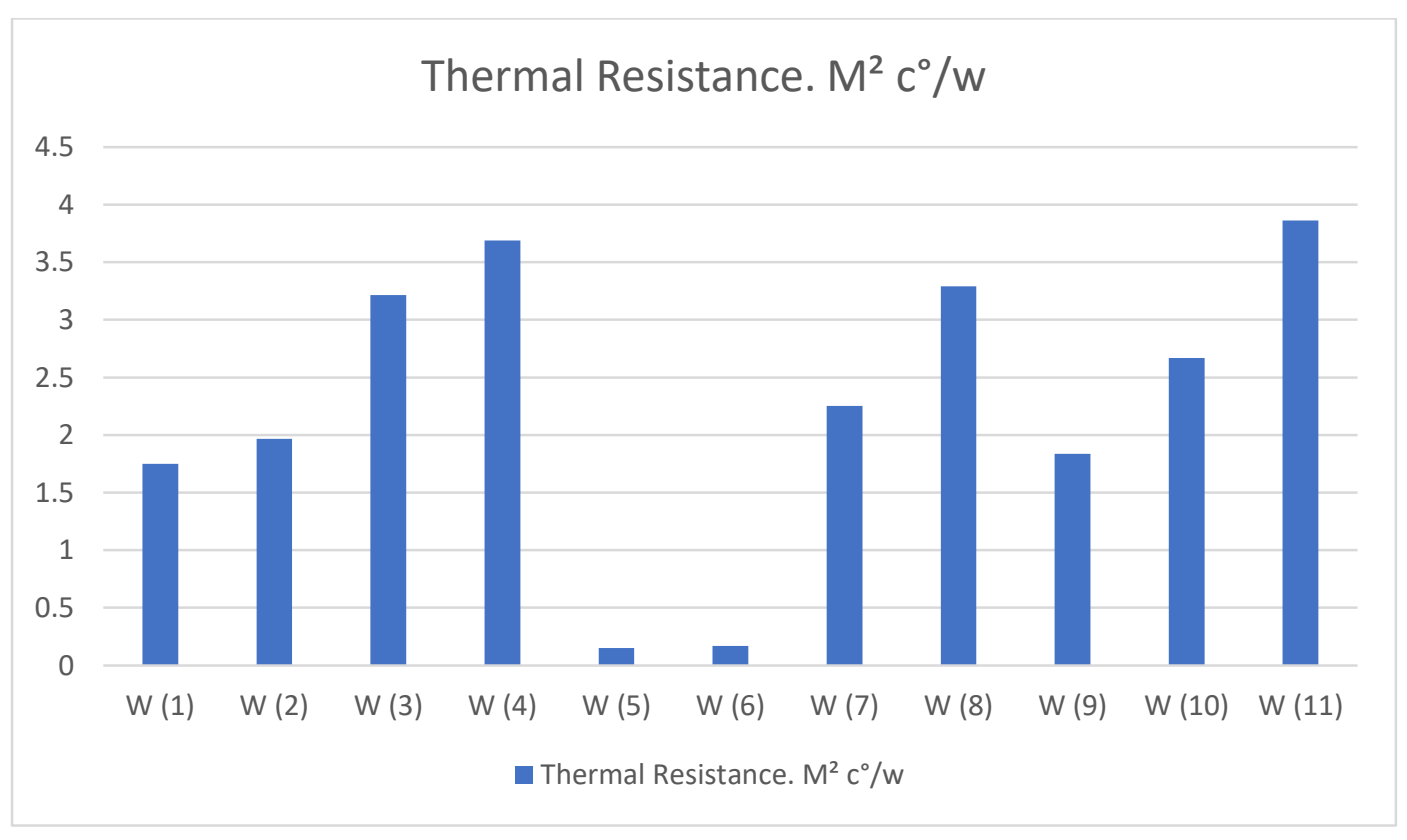

Figure 3. Explain the thermal resistance for eleven examples of walls. 
The comparison of the thermal resistance between eleven examples of wall explains that the example of $\mathrm{W}_{(11)}$ is the highest resistance. Also, this wall has the lowest heat flux density through the building wall during the summer season as showed in Figure $3 . \mathrm{W}_{(11)}$ is the highest resistance percentage of $50 \%$ with the most traditional hollow brick used in walls - $\mathrm{W}_{(2)}$.

The result according to that the new hollow brick can use in the green building because it saves thermal comfort inside the building and reduce the heat transfer from the external envelop of the building.

\section{The second phase had analyzed the thermal behavior of new hollow bricks.:}

After the two previous studies which have proved the benefits and role of new hollow brick to saving the thermal comfort indoor building, this part will explain the energy consumption in two dimensions in heating and cooling inside building.

\section{The energy consumption for cooling in building:}

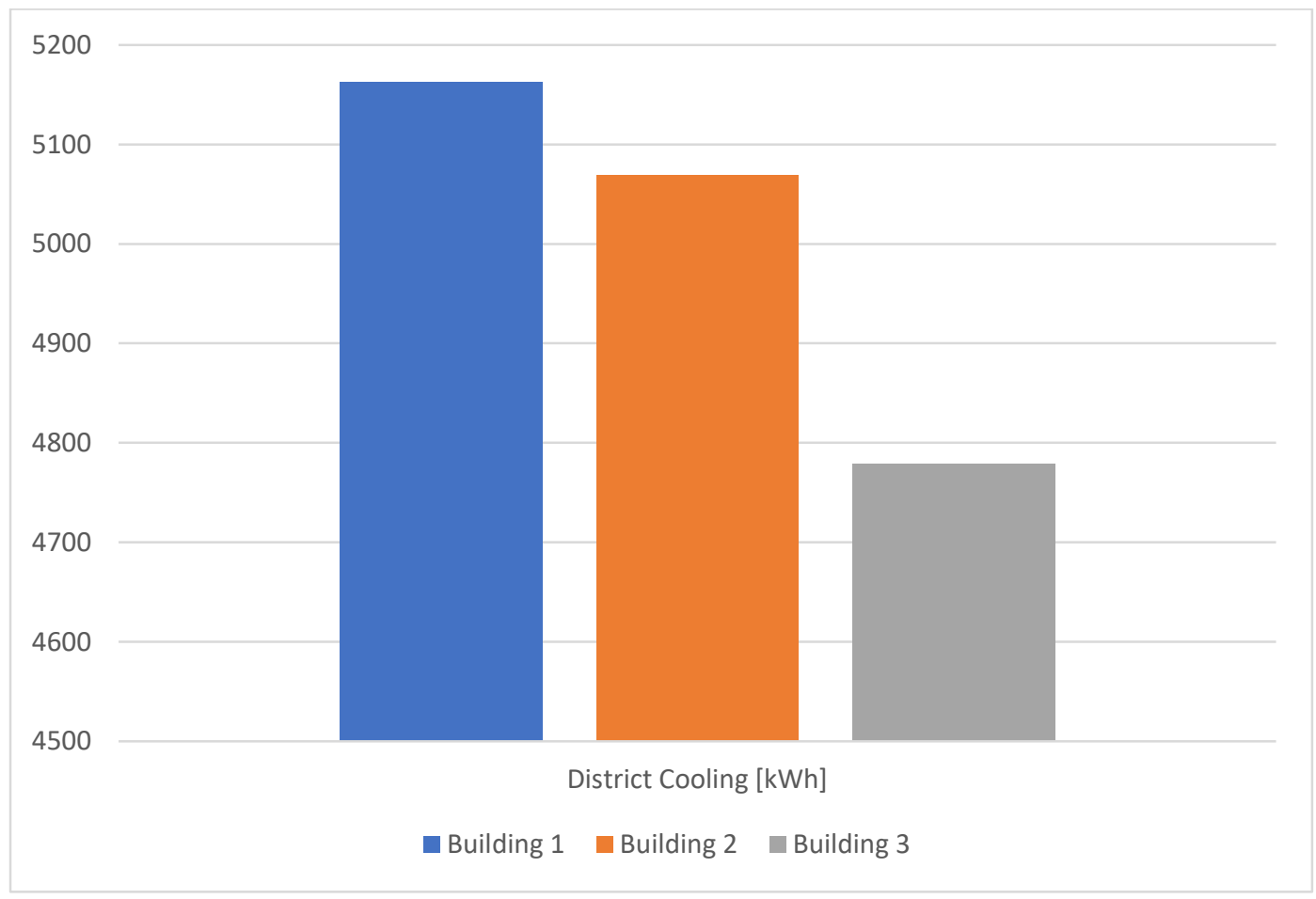

Figure 4. Explain the energy consumption for cooling in building from design builder simulation program.

Result for this chart the building (3) which used the new hollow brick helping to save the energy. Its energy consumption is lower than another two buildings in the case of cooling buildings. Building 3 is the lowest the energy consumption for cooling percentage of $7.5 \%$ with the most traditional model - building 1 as showed in Figure 4. 


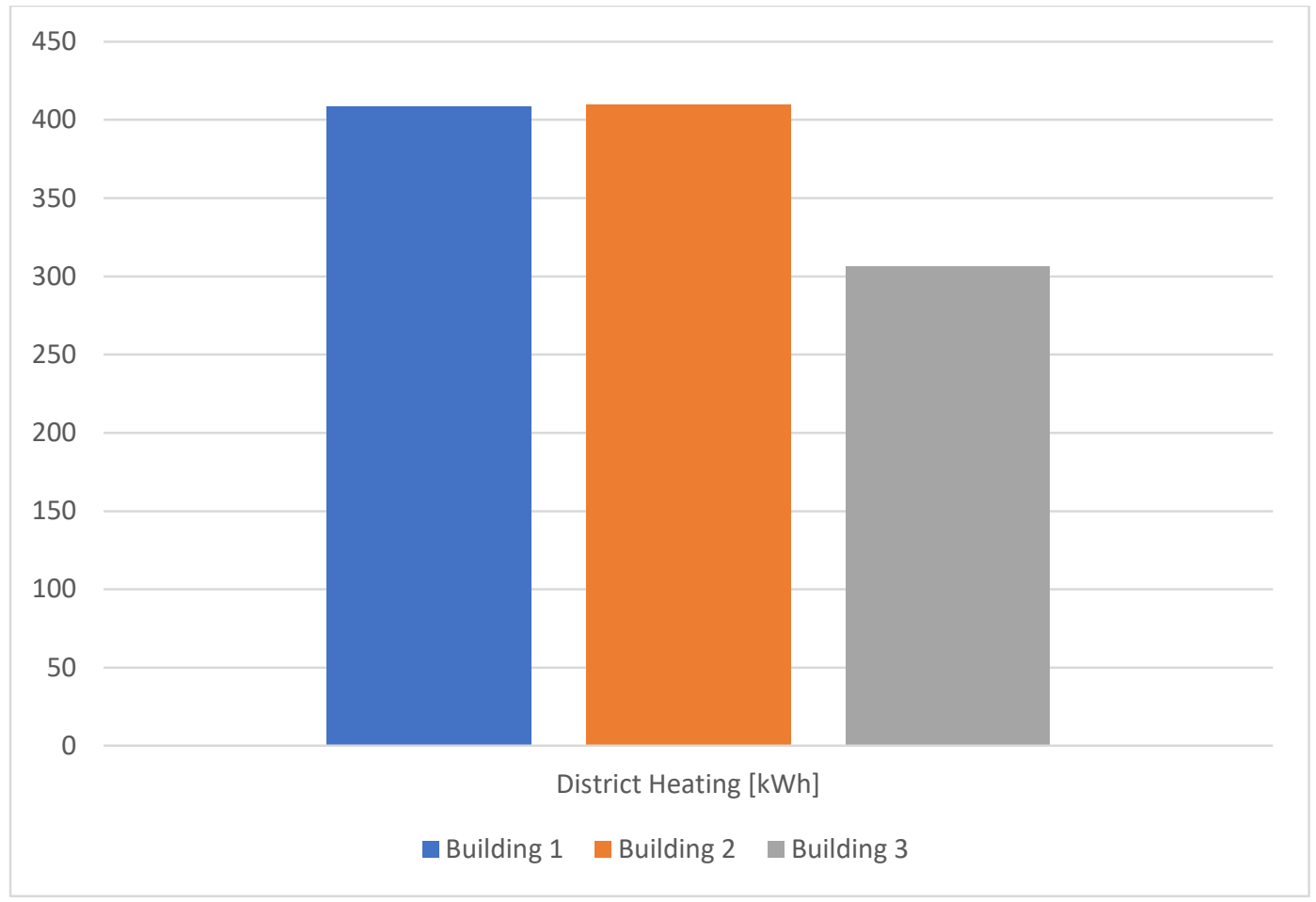

Figure 5. Explain the energy consumption for heating in building from the designbuilder simulation program.

The result for this chart is building (3) which used the new hollow brick helping to save energy. Its energy consumption is lower than another two buildings in the case of heating buildings as showed in Figure 5. Building 3 is the lowest the energy consumption for heating percentage of $25 \%$ with the most traditional model building 1 .

Consequently, using the new hollow brick help to improve the thermal comfort indoor the building that decreases use heating and cooling mechanical lowest. Therefore, it helps to save energy consumption in the building.

The cost : In this part compare the result of analysis models in the design-builder simulation program about the structure costs, the HVAC Costs, and the lighting costs for the three models of buildings. Therefore, that will appear role of the three models in reducing costs. Additionally determine which one of them more efficient in decrease the cost than others. 


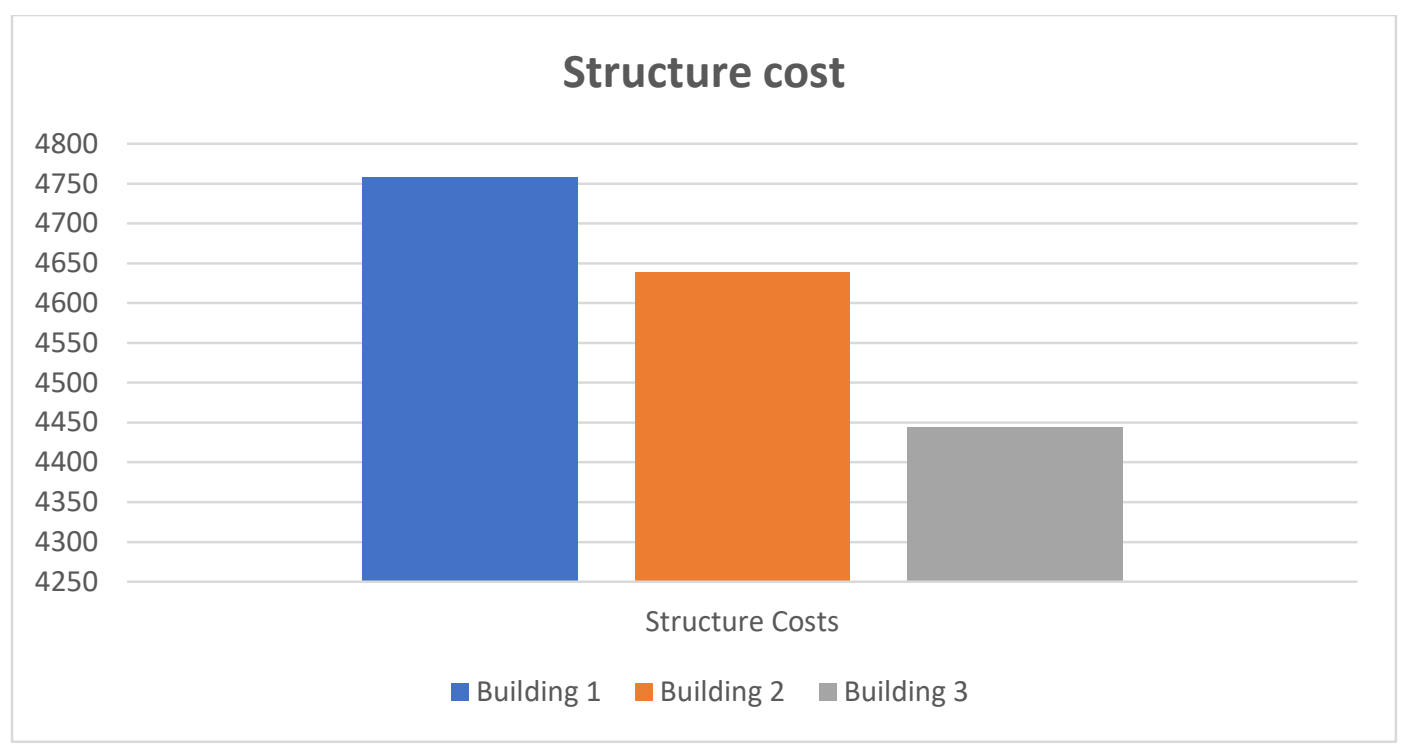

Figure 6. Explain the cost of structure for the three models of building from the designbuilder simulation program.

The result for this chart, the structure cost for the building 3 which used the new hollow brick is lower than another two buildings as showed in Figure 6. Building 3 is the lowest structure cost for the building percentage $7 \%$ with the most traditional model - building 1.

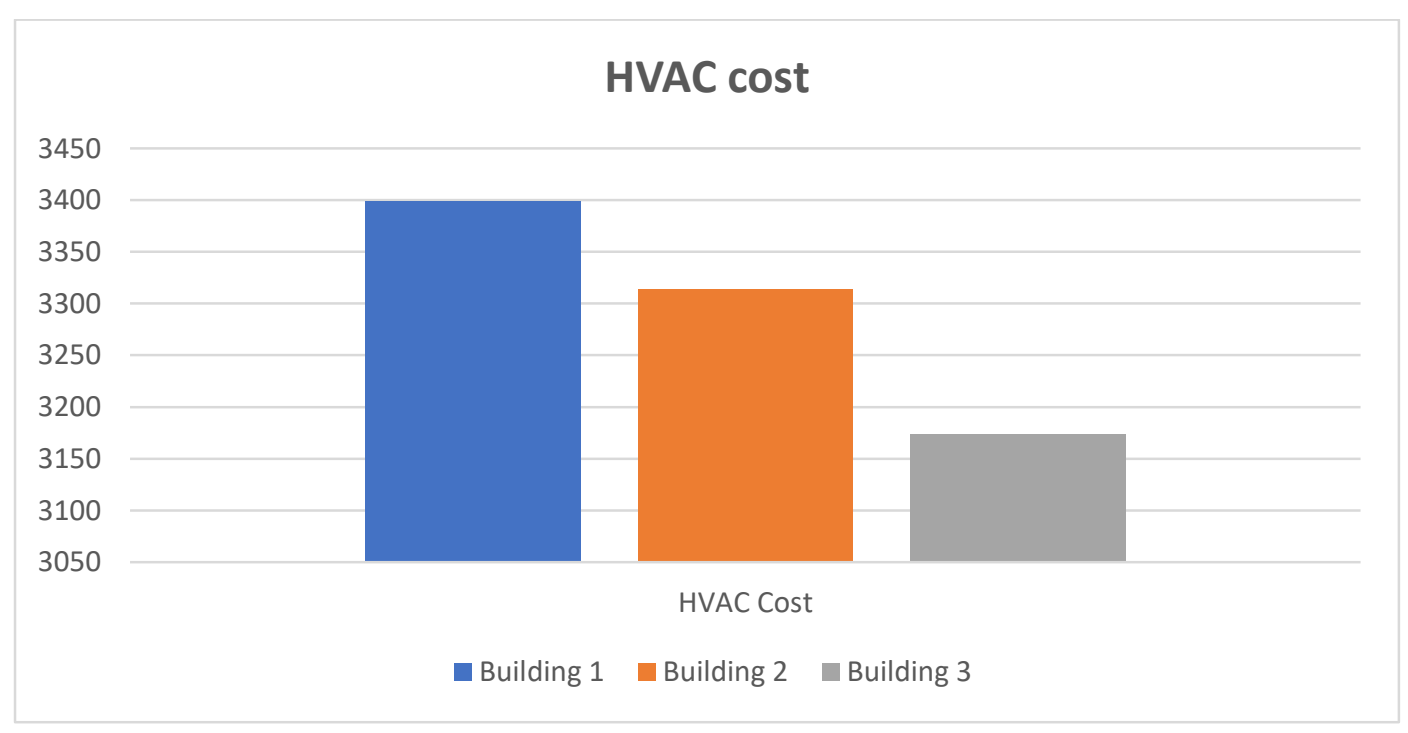

Figure 7. Explain the cost of HVAC consumption for the three models of building from the design-builder simulation program. 
The result for this chart, the HVAC cost for the building 3 which used the new hollow brick is lower than another two buildings as showed in Figure 7. It depends on reducing the energy consumption cooling and heating mechanical as has showed in second phase. Building 3 is the lowest HVAC cost percentage $7 \%$ with the most traditional model - building 1.

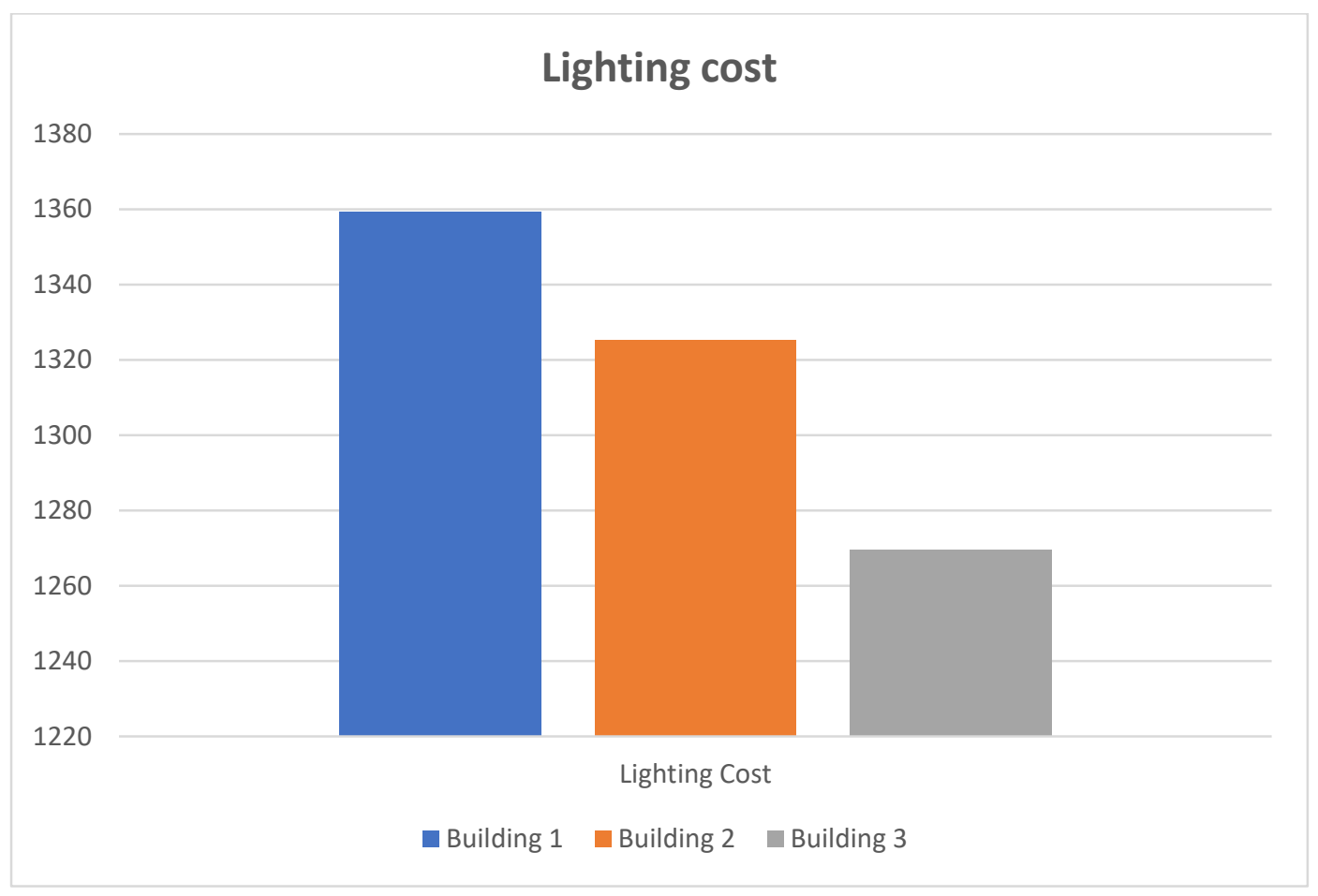

Figure 8. Explain the cost of lighting consumption for the three models of building from the design-builder simulation program.

The result for this chart, the lighting cost for building 3 which used the new hollow brick is lower than another two buildings as showed in Figure 8. Building 3 is the lowest lighting cost percentage $7 \%$ with the most traditional model - building 1 .

Consequently, the building which used the new hollow brick decrease cost of the structure, lighting consumption, and HVAC consumption. Finally, using the new hollow brick will decrease the energy consumption and the cost with the ratio of $7 \%$ in every part during a building's life cycle.

\section{Conclusion:}

the main goal of this study was to change the shape of concrete hollow brick to decrease cost during a building's life cycle and improve the heat transfer coefficient. The specific concluding remarks related to the findings presented herein can be drawn from this study are: 
- The results of this study indicate that the changing shape of concrete hollow brick with the same material is certainly feasible.

- Based on the experimental results, The new concrete hollow brick will achieve high Compressive strength compared with the wanted at the Egyptian code (N 204 - 2015).

- compressive strength highest percentage $65 \%$ in the case of nonload bearing concrete hollow brick.

- compressive strength highest percentage $12 \%$ in the case of nonload bearing concrete hollow brick.

- The new concrete hollow brick has made improvements also including decrease cost during a building's life cycle: from planning to design, construction, operation, maintenance, renovation, and demolition, Such as:

○ planning to design: it stable for all typing of building so the designer could take his freedom in planning and designing buildings.

○ Construction:

- using the new hollow brick will decrease the structure cost with a ratio of $7 \%$.

- decrease the time of building construction. The decreasing time of construction to the project will decrease the cost and reduction the possibility of risking raise prices of materials for another part of the construction.

- does not need material to Bond it together, so that saves the cost which will pay to this material.

- reduce the number of construction laborers. Reducing the number of construction laborers will reduction the payroll of construction laborers.

○ operation: the resistance for heat transfer highest percentage 50\%. So decrease the heat transfer throw wall which will increase the feeling of a comfortable indoor building.

- achieve to thermal comfort can impact directly in decreased use equipment (which is used for cooling in summer- heating in winter) and decrease use equipment that affects energy consumption.

- Reduce the energy consumption for cooling with a ratio of $7.5 \%$.

- Decrease the energy consumption for heating with a ratio of $25 \%$.

- Reduce HVAC cost with a ratio of $7 \%$.

- Decrease lighting cost with a ratio of $7 \%$. maintenance: can replace the brick with another one so easy

- renovation: can change the wall place easily.

○ demolition: it is Easily disassembled because it isn't found Bonding material. 


\section{References:}

\subsection{Journal Article}

[1] N.Idrus, H.C.Siong, "AFFORDABLE AND QUALITY HOUSING THROUGH THE LOW-COST HOUSING, PROVISION IN MALAYSIA", 26 June 2008.

[2] W.Yue, H.Xingzhu, W.Lin, "The Development Research of Green Economic in Capital Cities in Shandong" , Elsevier, Energy Procedia 5, 2011, pn( 130-134) .

[3] The Online Code Environment and Advocacy Network, " The Cost of Building Green Data \& Analysis", Navigating the World of Energy Codes | www.bcap-ocean.org.

[4] R.Ries , M.M. Bilec , N.M.Gokhan \& K.L.Needy, " THE ECONOMIC BENEFITS OF GREEN BUILDINGS: A COMPREHENSIVE CASE STUDY", The Engineering Economist, ISSN: 0013-791X print / 1547-2701 online, pp.259-295, 2007.

[5] M. Samer, "Towards the implementation of the Green Building concept in agricultural buildings: a literature review" , Agric Eng Int: CIGR Journal, Open access at http://www.cigrjournal.org, Vol. 15, No.2, July, 2013, pn $25-46$.

[6] D.Husain, R.Prakash," Ecological footprint reduction of built envelope in India", Journal of Building Engineering, Volume 21, January 2019, Pages 278-286.

[7] Evyatar, E., " The Application of Urban Climate Research in the Design of Cities" , ADVANCES IN BUILDING ENERGY RESEARCH, ISSN 1751-2549 (Print), 1756-2201 1Onlrnel • www.earthscanjournals.com, 2008, PAGES 95-121.

[8] A.W.Bruno, D.Gallipoli, C.Perlot, H,Kallel," Thermal performance of fired and unfired earth bricks walls", Journal of Building Engineering, Volume 28, March 2020, 101017.

[9] Elena, P., Mariia, P., Alexandr, G., Xenyiya, R., "Concept Project of Zero Energy Building" , ELSEVIER, Procedia Engineering 100 , 2015 , pn 1505 - 1514.

[10] M.J.Romero, F.Aguilar, P.G.Vicente, “Analysis of design improvements for thermal bridges formed by double-brick façades and intermediate slabs for nZEB residential buildings in Spain", Journal of Building Engineering, Volume 44, December 2021, 103270 .

[11] T.Zahra,J.Tham,M. Asada, "Compressive strength and deformation characteristics of concrete block masonry made with different mortars, blocks and mortar beddings types", Journal of Building Engineering, Volume 38, June 2021, 102213.

[12] N.Laaroussi, G.Lauriat, S.Raefat, M.Garoum, M.Ahachadc,” An example of comparison between ISO Norm calculations and full CFD simulations of thermal performances of hollow bricks", Journal of Building Engineering, Volume 11, May 2017, Pages 69-81.

[13] R.Bassiouny, M. R.O.Ali, E. H.NourEldeen, "Modeling the Thermal Behavior of Egyptian Perforated Masonry Red Brick Filled with Material of Low Thermal Conductivity", Journal of Building Engineering, Volume 5, March 2016, Pages 158-164. 
[14] Y.Gao, F.XiMeng, Z.Wang, M.Zhang, H.Yu, W.Gao, "Thermal behavior analysis of hollow bricks filled with phase-change material (PCM)", Journal of Building Engineering, Volume 31, September 2020, 101447.

[15] S.N.Shah, K.HungMo, S.P.Yap, M.K.H.Radwan, "Towards an energy efficient cement composite incorporating silica aerogel: A state of the art review", Journal of Building Engineering, Volume 44, December 2021, 103227.

[16] S.Ray, M.Haque, Md.N.Sakib, A.F.Mita, M.D. M.Rahman, B.B.Tanmoy, "Use of ceramic wastes as aggregates in concrete production: A review" Journal of Building Engineering,Volume 43, November 2021, 102567.

[17] M.Srivastava, V.Kumar, "The methods of using low cost housing techniques in India", Journal of Building Engineering, Volume 15, January 2018, Pages 102-108.

[18] A.M.Heniegal, O.M.O.Ibrahim, N.B.Frahat,M.Amin, "New techniques for the energy saving of sustainable buildings by using phase change materials", Journal of Building Engineering, Volume 41, September 2021, 102418.

[19] S.Seyam, "The impact of greenery systems on building energy: Systematic review", Journal of Building Engineering, Volume 26, November 2019, 100887.

[20] A.W.Bruno, D.Gallipoli, C.Perlot, H,Kallel,” Thermal performance of fired and unfired earth bricks walls", Journal of Building Engineering, Volume 28, March 2020, 101017.

[21] J.Jazaeri, R. L.Gordon, T.Alpcan, "Influence of building envelopes, climates, and occupancy patterns on residential HVAC demand", Journal of Building Engineering,Volume 22, March 2019, Pages 33-47.

[22] J.SenmiaoLi,S.Chen,X.Wang,Z.Jiang, C.Shen, "Energy-efficiency strategies of residential envelope in China's Hot Summer-Cold Winter Zone based on intermittent thermal regulation behaviour", Journal of Building Engineering, Volume 44, December 2021, 103028

[23] A.Edun, C.H.Vermette, "Energy and environmental impact of recycled end of life tires applied in building envelopes", Journal of Building Engineering, Volume 39, July 2021, 102242.

\subsection{Book:}

[24] J.H.Lienhard IV, J.H.Lienhard V, “A HEAT TANSFER TEXTBOOK”, Fifth edition, 2019, Cambridge Massachusetts. 